\title{
A Case Study of Engineering PhD Students' Career Decision-Making Processes using a Bounded Agency Model
}

\author{
Romina B. da Costa $\mathrm{a}^{\mathrm{a}, *}$ \\ ${ }^{a}$ University of Maryland, College Park, United States \\ *Corresponding author: Email: rcosta2@umd.edu \\ Address: University of Maryland, College Park; College Park, Maryland; United States
}

As an increasingly competitive, globalized economy continues to reshape higher education in the $21^{\text {st }}$ century, scholars, institutions and national governments are calling for a more diverse academic workforce, particularly in science, technology, engineering and mathematics (STEM) disciplines (Beasley and Fischer 2012; Blickenstaff 2017; C. Hill, Corbett, and St Rose 2010; Ramsey, Betz, and Sekaquaptewa 2013). This focus on making STEM more inclusive has often centered on the recruitment, retention and advancement of women professors, who continue to be underrepresented in these fields (Beasley and Fischer 2012; Blickenstaff 2017; C. Hill, Corbett, and St Rose 2010; Whitten, Foster, and Duncombe 2003). However, recent research reveals that the representation of women in STEM fields in US academic institutions continues to decrease sharply as one moves up the academic career ladder (Ehrenberg 2010; Griffith 2010; Beede et al. 2011; Beasley and Fischer 2012; P. W. Hill, Holmes, and McQuillan 2014; Leslie et al. 2015). This phenomenon, often termed the "leaky pipeline" for women in STEM, is described as both persistent and pervasive.

There are more similarities than differences across industrialized regions. Many of the patterns seen in the United States are also seen in other Anglophone countries such as in the UK, as well as in the European Union (EU) in general. In fact, many western European countries lag behind the US in terms of the percentage of female doctoral recipients in the sciences, and the pay gap between men and women scientists is bigger in the EU than in the US (Shen 2013). Concern over gender equality in universities in the EU has seen considerable growth in the last few decades (Rees
2007). Statistics showing that women constituted over 50 percent of undergraduates but made up only 14 perent of professorships in the region raised alarm among policy makers in the region, resulting in a push to recruit and retain more women into institutions of higher learning, particularly within the science disciplines (Rees 2007). A similar pattern was revealed in Switzerland, with the erosion of women at the higher levels of the academic career ladder (Widmer et al. 2008). Despite the increasing numbers of women, especially at the undergraduate level in Germany, the horizontal segregation of female students into the languages, humanities, medicine, and biological sciences acts as a barrier to equality; women are still greatly underrepresented in the sciences and technical disciplines (Müller 2007). While the contexts are different, these statistics ring familiar in relation to the US higher education context as well.

The bulk of research on STEM attrition has focused on K-12 education and on college major selection at the bachelor's level. There are also studies on career transitions within academia, focusing on the tenure process and gender differences in promotion rates (Canizares 2009). However, few studies have focused on graduate and postgraduate educational experiences, or on career transitions following graduate education. Moreover, the theoretical frameworks commonly used in the literature on graduate education address the experiences of individuals in a way that emphasizes individual choice and agency. These frameworks do not adequately integrate an analysis of structural elements tied to the attributes of the university as an organization, thus omitting the role of the university itself in bounding or limiting individual agency and choice. 
The purpose of this in-depth, qualitative case study is to explore reasons for STEM attrition at an understudied point in the academic pipeline, by examining how men and women $\mathrm{PhD}$ students in engineering disciplines in a large, public, research institution in the USA make career decisions following their graduate education. More specifically, this study seeks to explore gender differences in engineering $\mathrm{PhD}$ students' career decisions through a bounded agency model. This framework allows for an acknowledgement of the role of structural conditions in limiting individuals' perceptions of their feasible alternatives, leading to a fuller understanding of the ways in which the university as an organization impacts the behaviors and choices of $\mathrm{PhD}$ students nearing the end of their programs. This bounded agency approach is able to better integrate an understanding of structural and organizational factors pertaining to the university as an institution and its effects on individual agency and decision-making. In order to illuminate potential gender differences, this study involves a sample consisting of both male and female participants, so that comparisons may be drawn.

The theoretical framework guiding this study draws heavily from Men and Women of the Corporation (Kanter 1977). In her work, Kanter conceptualized the fates and trajectories of men and women within an organizational context as being inextricably linked with organizational structures. In applying this framework to my study, I similarly assume the university to be an organization within which structures of opportunity and power shape the choices, dilemmas and decisionmaking of individual men and women. This assumption allows for an examination of the complex relationship between individuals and the university as an organization, leading to a fuller understanding of the ways in which the university impacts the behaviors and choices of people within it.

Although this study examines the career decisionmaking processes of engineering $\mathrm{PhD}$ students in the context of a large, public research institution in the United States, this has relevance for institutions of higher learning worldwide. The US has long been the destination of choice for students around the world who choose to study outside of their own country, such that many nations conform closely to the US model for research institutions (de Wit 2001; Bok 2013). The American system has been further strengthened due to the adoption of English as the common scientific language since the mid-twentieth century, and the US dominance of the Internet (Altbach 2011). Better understanding how engineering $\mathrm{PhD}$ students in the US experience their graduate education, and the structural and organizational factors affecting their career decisions can lead to insights on diversifying the professoriate in engineering and perhaps other STEM disciplines in similar institutions elsewhere. Although one must be cautious in assuming that any findings have universal application, this study can lend insight as to the effects of policies promoting gender diversity in STEM, including the limitations of current efforts to feminize the STEM professoriate. Additionally, a better understanding of how engineering $\mathrm{PhD}$ students approach their career decisions and approach their job search at the end of their graduate programs can have implications for engineering $\mathrm{PhD}$ students' career development and for university career services both in the US and beyond.

This research seeks to propose a new model for understanding engineering $\mathrm{PhD}$ graduates' approach to career decision-making. This bounded agency model combines structural and organizational factors with individual level factors in illuminating how students' agentic choice in career decision-making is bounded by both structural and dispositional barriers affecting their decision to pursue any given career path. A feminist gender analysis of the data will also allow for the highlighting of differences between men and women's decision-making patterns, demonstrating how structural and dispositional barriers may be considered and weighed differently by men and women engineering PhDs. An understanding of these differences can have important implications for graduate education in maledominated disciplines such as engineering, and for efforts to diversify the professoriate. 


\section{References}

Altbach, Philip G. 2011. "Patterns of Higher Education Development." In American Higher Education in the Twenty-First Century, edited by Philip G. Altbach, Patricia J. Gumport, and Robert O. Berdahl, 2nd ed., 15-36. Baltimore, MD: The Johns Hopkins University Press.

Beasley, Maya A., and Mary J. Fischer. 2012. "Why They Leave: The Impact of Stereotype Threat on the Attrition of Women and Minorities from Science, Math and Engineering Majors." Social Psychology of Education 15 (4): 427-48. doi:10.1007/s11218-012-9185-3.

Beede, D. N., T. A. Julian, D. Langdon, G. McKittrick, B. Khan, and M. E. Doms. 2011. "Women in STEM: A Gender Gap to Innovation."

Blickenstaff, Jacob Clark. 2017. "Women and Science Careers: Leaky Pipeline or Gender Filter?" 0253 (July). doi:10.1080/09540250500145072.

Bok, Derek. 2013. "Introduction." In Higher Education in America, Revised Ed, 9-27. Princeton, NJ.: Princeton University Press.

Canizares, Claude R. 2009. "Gender Differences at Critical Transitions in the Careers of Science, Engineering and Mathematics Faculty." In Meeting the Challenges of an Increasingly Diverse Workforce: Women in Astronomy and Space Science, edited by Anne L. Kinney, Diana Khachadourian, Pamela S. Millar, and Colleen N. Hartman, 35-42. College Park, MD. doi:10.1016/s0399-8320(09)73155-0.

Ehrenberg, Ronald G. 2010. "Analyzing the Factors That Influence Persistence Rates in STEM Field, Majors: Introduction to the Symposium." Economics of Education Review 29 (6). Elsevier Ltd: 888-91.

doi:10.1016/j.econedurev.2010.06.012.

Griffith, Amanda L. 2010. "Persistence of Women and Minorities in STEM Field Majors: Is It the School That Matters?" Economics of Education Review 29 (6). Elsevier Ltd: 911-22. doi:10.1016/j.econedurev.2010.06.010.

Hill, Catherine, Christianne Corbett, and Andresse St
Rose. 2010. Why So Few? Women in Science, Technology, Engineering, and Mathematics. Association of University Women. doi:10.1002/sce.21007.

Hill, P. W., M. A. Holmes, and J. McQuillan. 2014. "The New STEM Faculty Profile: Balancing Family and Dual Careers." In Advances in Gender Research, Volume 19: Gender Transformation in the Academy, edited by Vasilikie Demos, Catherine White Berheide, and Marcia Texler Segal, 3-20. Bingley, UK: Emerald Group.

Kanter, Rosabeth Moss. 1977. Men and Women of the Corporation. New York, NY: Basic Books.

Leslie, Sarah-Jane, Andrei Cimpian, Meredith Meyer, and Edward Freeland. 2015. "Academic Disciplines." Science 347 (6219): 23-34. doi:10.1081/E-EWS.

Müller, Ursula. 2007. "Between Change and Resistance: Gender Structures and Gender Cultures in German Institutions of Higher Education." In Women, Universities, and Change: Gender Equality in the European Union and the United States, edited by Mary Ann Danowitz Sagaria, 23-41. New York, NY.

Ramsey, Laura R., Diana E. Betz, and Denise Sekaquaptewa. 2013. "The Effects of an Academic Environment Intervention on Science Identification among Women in STEM." Social Psychology of Education 16 (3): 377-97. doi:10.1007/s11218-0139218-6.

Rees, Teresa. 2007. "Pushing the Gender Equality Agenda Forward in the European Union." In Women, Universities, and Change: Gender Equality in the European Union and the United States, edited by Mary Ann Danowitz Sagaria, 7-21. New York, NY: Palgrave Macmillan.

Shen, Helen. 2013. "Mind the Gender Gap." Nature 495 (7439): 22-24. doi:10.1111/j.1742-

1241.2011.02659.x.

Whitten, Barbara L., Suzanne R. Foster, and Margaret L. Duncombe. 2003. "What Works for Women in Undergraduate Physics?" ADVANCE Library Collection, 295. doi:10.1063/1.1620834.

Widmer, Maya, Regula Julia Leemann, Heidi Stutz, and 
Katrin Schonfisch. 2008. "Cooling Out? Gender and Research in Switzerland." In Gender Equality Programs in Higher Education: International Perspectives, edited by S. Grenz, B. Kortendiek, M. Kriszio, and A. Löther. VS Verlag Für
Sozialwissenschaften.

Wit, J.W. M. de. 2001. "Internationalisation of Higher Education in the United States of America and Europe." 